\title{
Implementasi Peraturan Presiden Nomor 13 Tahun 2018 dalam Pendirian Perseroan Terbatas
}

\author{
Lidya Permata Dewi ${ }^{1}$
}

${ }^{1}$ Program Studi Magister (S2) Kenotariatan Fakultas Hukum Universitas Udayana, BaliIndonesia, E-mail: lidyapermatadewii@gmail.com

\begin{tabular}{l}
\hline Info Artikel \\
\hline Masuk : 28 Januari 2019 \\
Diterima: 20 Maret 2019 \\
Terbit : 30 April 2019 \\
\\
Keywords : \\
Limited Liability Company (PT), \\
Money Laundering, Beneficiary
\end{tabular}

Kata kunci:

Perseroan Terbatas (PT),

Pencucian Uang, Pemilik

Manfaat

Corresponding Author:

Lidya Permata Dewi.

E-mail:

lidyapermatadewii@gmail.com

DOI :

10.24843/AC.2019.v04.i01.p01

\begin{abstract}
In order to overcome and eradicate the crime of money laundering the president has issued Presidential Regulation No. 13 of 2018 concerning The Implementation of the Principles of Recognizing Beneficial Owners of Corporations in the Context of Prevention and Eradication of Acts Crime of Money Laundering and Crime of Terrorism Funding, so the problem in this study is how is the implementation of Presidential Regulation Number 13 of 2018 in the establishment of a limited liability company and whether the beneficial owner has implemented it. This study uses empirical legal research methods, because it wants to know how the implementation of Presidential Regulation No. 13 of 2018 in the establishment of a limited liability company and whether the beneficial owner has implemented it, to find out this study uses the facta approach and the statute approach. The results of this study are officials appointed by the company to inform the data of the beneficial owner of a company in accordance with Article 18 paragraph (3) of the Presidential Regulation No. 13 of 2018, one of which is a Notary, that the implementation of Presidential Regulation No. 13 of 2018 in the establishment of limited liability companies is in the form of a Statement in which the beneficial owner states that it is true as the owner and depositor of funds within the company, but not all notaries want to implement Presidential Regulation No. 13 of 2018 because, assuming that it will make a boomerang for the notary find out who is actually the beneficial owner of the company and here the notary is still subject to and cling to the Act of Notary Position which is only pouring out what the parties want into the deed.
\end{abstract}

\begin{tabular}{l}
\hline Abstrak \\
\hline Demi menanggulangi dan memberantas kejahatan tindak pidana \\
pencucian uang ini presiden telah membuat peraturan Presiden No. \\
13 pada tahun 2018 mengenai Penerapan Prinsip Mengenali \\
Pemilik Manfaat Dari Korporasi Dalam Rangka Pencegahan dan \\
Pemberantasan Tindak Pidana Pencucian Uang dan Tindak Pidana \\
Pendanaan Terorisme, sehingga permasalahan dalam penelitian ini \\
adalah bagaimanakah implementasi Peraturan Presiden Nomor 13 \\
Tahun 2018 dalam pendirian perseroan terbatas dan apakah pemilik \\
manfaat sudah ada yang menerapkannya. Penelitian ini \\
menggunakan metode penelitian hukum empiris, dikarenakan ingin \\
mengetahui bagaimanakah implementasi Peraturan Presiden Nomor \\
13 Tahun 2018 dalam pendirian perseroan terbatas dan apakah \\
pemilik manfaat sudah ada yang menerapkannya, untuk \\
mengetahuinya penelitian ini menggunakan suatu metode dengan
\end{tabular}


pendekatan fakta atau istilah asingnya the facts approach dan dengan pendekatan peraturan perundang-undangan atau istilah asingnya the statute approach. Hasil penelitian ini adalah pejabat yang ditunjuk oleh perusahaan untuk menginformasikan data pemilik manfaat dari suatu perusahaan sesuai pada Pasal 18 ayat (3) Peraturan Presiden Nomor 13 Tahun 2018 yang salah satunya adalah Notaris, bahwa implementasi Peraturan Presiden Nomor 13 Tahun 2018 dalam pendirian perseroan terbatas adalah dalam bentuk Surat Pernyataan yang di dalamnya adalah pemilik manfaat menyatakan bahwa memang benar selaku pemilik dan penyetor dana di dalam perusahaan, namun tidak semua notaris mau menerapkan Peraturan Presiden Nomor 13 Tahun 2018 tersebut karena, beranggapan bahwa akan menjadikan bumerang tersendiri bagi Notaris yang mengetahui siapa sebenarnya pemilik manfaat dari perusahaan tersebut dan disini notaris masih tunduk dan berpegang teguh dengan Undang-Undang Jabatan Notaris yaitu hanya menuangkan apa yang menjadi keinginan para pihak ke dalam akta.

\section{Pendahuluan}

Pada suatu Negara telah banyak adanya bentuk kejahatan baik yang dilakukan oleh perorangan maupun korporasi. Dimana suatu kejahatan ini dapat menghasilkan kekayaan yang banyak, seperti halnya pencucian uang atau money laundering. Ini merupakan pidana yang mempunyai julukan sebagai "Kejahatan Kerah Putih" atau istilah asingnya white collar crime dan terorisme. ${ }^{1}$ Money Laundering merupakan rangkaian kegiatan dengan adanya suatu kegiatan yang ditindaki oleh seseorang dan atau organisasi dengan sejumlah uang haram yang diperoleh dari kejahatan bermaksud untuk menggelapkan dan menyembunyikan asal usul uang itu dari pemerintah/instansi yang berwenang sesuai yang diungkapkan oleh Sutan Remy Sjahdaeni. ${ }^{2}$ Maraknya kasus pencucian uang dapat mengancam turunnya kestabilitasan dan integritas system perekonomian di Negara Indonesia, yaitu melibatkan kumpulan orang dari suatu perusahaan sebagai tempat atau wadah diputarnya uang tersebut. Perseroan Terbatas (PT) berdiri dengan proses pembuatan akta pendirian dan melakukan pengesahan badan hukum yang disahkan oleh Kementrian Hukum dan HAM dan dibantu aksesnya melalui jasa pejabat Notaris.

Pengertian korporasi pada aturan Presiden tahun 2018 nomor 13 Pasal 1 adalah kumpulan segenap orang dengan suatu kekayaan yang tersusun yang berbentuk seperti badan hukum atau tidak berbadan hukum. Tidak semua Perseroan Terbatas (PT) sebagai tempat untuk menyimpan kekayaan hasil dari tindak pidana pencucian uang, namun sejak dikeluarkannya aturan oleh presiden dengan nomor 13 pada tahun 2018 mengenai cara penerapan prinsip untuk mengenali pemilik manfaat dari perusahaan atau korporasi yaitu dalam rangka untuk pencegahan dan pemberantasan kasus pidana money laundering

\footnotetext{
${ }^{1}$ Kurniawan, Iwan. (2013). Perkembangan Tindak Pidana Pencucian Uang (Money Laundering) dan Dampaknya Terhadap Sektor Ekonomi dan Bisnis. Jurnal Ilmu Hukum Riau, 3(2). h. 4.

2 Yani, Ahmad, Mas. (2013). Kejahatan Pencucian Uang (Money Laundering) (Tinjauan UndangUndang Nomor 8 Tahun 2010 Tentang Pencegahan Dan Pemberantasan Tindak Pidana Pencucian Uang). E-Journal Widya Yustisia, 1(1). h. 21.
} 
dan pidana pendanaan kepada terorisme ini adalah salah satu aturan bagi para pemilik manfaat dari suatu Perseroan Terbatas (PT).

Perusahaan merupakan salah satu sendi utama dalam berkehidupan masyarakat modern karena merupakan salah satu kegiatan manusia untuk memenuhi faktor ekonomi dalam kehidupan kesahariannya. Kegiatan perusahaan merupakan kegiatan ekonomi yang dilakukan oleh organisasi secara terbuka dan berkesinambungan. ${ }^{3}$

Aturan Pasal 6 Kitab Undang - Undang Hukum Dagang, selanjutnya akan disebut ( KUHD ) pertama-tama mengatakan yakni untuk orang yang mendirikan sebuah PT, merekapun sebagai pendiri dan susunan pengurus perseroan terbatas mengenai harta berikut semua yang berhubungan dengan PT, membikin catatan, agar sewaktu - waktu catatan tersebut diperoleh dan diketahui untuk segala hak berikut kewajiban di dalam perusahaan tersebut, artinya setiap orang yang akan masuk sebagai pendiri di suatu perusahaan akan memiliki kekayaan yang telah dikumpulkan dan akan disetorkan penuh/beberapa persen ke dalam perusahaan dengan catatan segala hak dan kewajiban akan dicatat dan diatur pada akta perusahaan.

Berkaitan dengan hal tersebut di atas, pengertian perseroan di dalam Undang - Undang dengan nomor 40 pada tahun 2007 mengenai PT disebutkan dalam Pasal 1 angka 1 adalah suatu perusahaan yang berbadan hukum memiliki persekutuan modal, berdiri berdasarkan perjanjian, memiliki kegiatan usaha dengan tunduk kepada peraturan dan aturan tentang pelaksanaannya. Istilah perseroan ini tidak asing lagi pada dunia perekonomian di Indonesia, karenanya susah dipungkiri PT bisa tumbuh serta berkembang di Indonesia. ${ }^{4}$ Usaha yang dominan dan paling relatif dalam dunia ekonomi adalah usaha dalam bentuk perseroan terbatas (PT), kenyataannya banyak perusahaan yang meningkatkan status badan hukumnya menjadi perseroan terbatas (PT), salah satu faktornya adalah karena bentuk perseroan terbatas (PT) merupakan sebuah tempat berusaha yang di dalamnya terjadi pengelompokan antara hak dan kewajiban antara pemegang saham dengan hak dan kewajiban perusahaan, dan perseroan terbatas (PT) ini juga dikenal dengan adanya pemisahan harta kekayaan. ${ }^{5}$ Pengaturan perusahaan yang berbadan hukum adalah dengan tujuan menjaga ketenangan dalam kegiatan usaha di dalam perusahaan, secara universal menjaga investasi ekonomi, namun suatu perusahaan yang berbadan hukum pastilah akan memberikan akibat hukum, karena tidak menutup kemungkinan akan ditafsirkan melakukan tindak pidana. ${ }^{6}$

Dalam era globalisasi terbangunnya kerjasama antar korporasi atau perusahaan diyakini ikut mempengaruhi struktur ekonomi di Indonesia. Pembangunan kerjasama ini seringkali berdampak positif dan negartif bagi setiap korporasi atau perusahaan. Dampak positifnya adalah banyak pemasukan saham-saham ke dalam perseroan dan membuat

${ }^{3}$ Kurniawan. (2014). Tanggung Jawab Pemegang Saham Perseroan Terbatas Menurut Hukum Positif. Jurnal Bagian Hukum Bisnis, Fakultas Hukum Universitas Mataram, Mimbar Hukum Volume 26, Nomor 1, Februari 2014, Halaman 70-83.

${ }^{4}$ Is, Muhamad, Sadi. (2016). Hukum Perusahaan di Indonesia. PT. Kharisma Putra Utama, Jakarta, p. 45

5 Santoso, Johari. (2000). Perseroan Terbatas sebagai Institusi Kegiatan Ekonomi yang Demokratis. Jurnal Hukum Ius Quia Iustum, 7(15), 194-203. h. 194.

${ }^{6}$ Listyowati, Nunuk. (2015). Tanggung Jawab Hukum Perseroan Terbatas Yang Belum Berstatus Badan Hukum. E-Jurnal Spirit Pro Patria, 1(2). h. 25. 
pesatnya perkembangan di dalam perusahaan, sedangkan dampak negatifnya adalah adanya pemasukan dan perputaran uang di dalam perusahaan yang tidak legal. Permainan uang ini sering disebut dengan money laundering. ${ }^{7}$

Sistem ekonomi nasonal dilaksanakan dengan berdasar atas kebebasan berpendapat yang didasarkan kekompakan bersama, tertib, ramah lingkungan berikut sifat kemandirian dan terus menjaga keseimbangan dan kemajuan berikut kesatuan ekonomi nasional. ${ }^{8}$ Pertumbuhan ekonomi pada tahun 2018 mengalami kenaikan dengan mencapai angka 5,3 \% (lima koma tiga persen) yang dibuktikan dengan peningkatan ekonomi di Indonesia menempati angka 5,1\% (lima koma satu persen) di tahun 2018, dikarenakan oleh meningkatkannya ekspor dan investasi di Negara Indonesia9, namun ditengah-tengah kenaikan ekonomi di Indonesia, telah marak terjadinya kasus pencucian uang dengan istilah asingnya money laundering. Money laundering ini telah dikenal secara luas pada tahun 2002 yakni sejak diundangkannya Undang - Undang dengan nomor 15 pada tahun 2002 mengenai tindakan pidana pencucian uang yang kemudian dirubah dengan Undang - Undang dengan nomor 25 pada tahun 2003, dengan perubahan terakhir dengan Undang - Undang dengan nomor 8 pada tahun 2010 mengenai cara pencegahan dan memberantasi tindakan pidana pencucian uang, setelah diundangkannya aturan ini maka barulah diketahui bahwa banyak perbuatan yang ternyata merupakan perbuatan pencucian uang.

Pencucian uang diartikan secara sederhana sebagai suatu proses yang menjadikan hasil kejahatan atau uang kotor yang diubah ke dalam bentuk yang tampak sah agar dapat digunakan dengan aman. ${ }^{10}$ Pencucian uang di Indonesia diselidiki banyak berasal dari tindak pidana korupsi, bahwa hasil dari korupsi ini sangat penting untuk dikaburkan atau dicuci agar terlihat uang tersebut bersih. Sebuah perbuatan pidana pencucian uang sangat membutuhkan wadah atau tempat untuk menempati dan memutar uang tersebut, tidak jarang wadah atau tempat tersebut adalah suatu perusahaan.

Pelaku tindak pidana pencucian uang adalah seseorang atau korporasi yang telah menggelapkan uang hasil korupsi dan membuat uang tersebut menjadi layak atau legal pendapatannya. Seseorang atau korporasi pada akhirnya akan mencari wadah atau tempat untuk uang hasil korupsi yakni dengan cara mendirikan suatu perusahaan atau perseroan terbatas. Pendirian suatu perseroan terbatas yang berbadan hukum akan melibatkan pejabat Notaris dalam pembuatan akta pendirian perseroan terbatas. Pembuatan akta tersebut diwajibkan untuk mengatur segala anggaran dasar perusahaan, dengan maraknya kasus tindak pidana pencucian uang, maka republic Indonesia oleh persidennya telah mengeluarkan aturan nomor 13 pada tahun 2018 mengenai si pemilik

${ }^{7}$ Hariman, Satria. (2016). Pertanggungjawaban Pidana Korporasi Dalam Tindak Pidana Sumber Daya Alam. Jurnal Bagian Hukum Pidana, Fakultas Hukum Universitas Muhammadiyah Kendari, Kendari, Mimbar Hukum Volume 28, Nomor 2, Juni 2016, Halaman 288-300

8 Budiono, Herlien. (2012). Arah Pengaturan Undang-Undang Nomor 40 Tahun 2007 tentang Perseroan Terbatas dalam Menghadapi Era Global. Jurnal Rechts Vinding: Media Pembinaan Hukum Nasional, 1(2), 187-198. h. 187.

9 DBS Bank Ltd (SG). Yuk Ketahui Seperti Apa Sistem Ekonomi Indonesia di 2018. Available from https://www.dbs.com/Indonesia-bh/blog/live-smart/yuk-ketahui-seperti-apa-sistem-ekonomi-indonesia-di2018.page. (Diakses 16 Desember 2018).

10 Garnasih, Yenti. (2016). Penegakan Hukum Anti Pencucian Uang Dan Permasalahannya Di Indonesia. PT. RajaGrafindo Persada, Jakarta, p. 15 
manfaat suatu perusahaan, yakni dimana pemilik manfaat dari suatu perusahaan tersebut jelas dengan berapa persen kekayaannya di dalam perusahaan, artinya bahwa di dalam perusahaan tidak terdapat kekayaan orang lain selain pemilik manfaat atau persero, bahwa, PP dengan nomor 13 pada tahun 2018 diantaranya mengatur mengenai pemilik manfaat dari sebuah : PT, Yayasan, Perkumpulan, Koperasi, CV, dan persekutuan firma. Pemilik manfaat dari perseroan terbatas pada PP dengan nomor 13 pada tahun 2018 dalam Pasal 4, setidaknya memiliki :

a. mempunyai lebih dari $25 \%$ saham dalam PT seperti yang telah tertuang di dalam AD;

b. memiliki lebih dari $25 \%$ hak suara dalam PT seperti yang telah tertuang di dalam AD;

c. memperoleh profit lebih dari $25 \%$ dari keuntungan PT per-tahunnya;

d. mempunyai hak untuk mengangkat, menggantikan dan memecat anggota direksi berikut komisaris;

e. berwenang dan berkuasa untuk menghasut dan menyetir PT dan tidak perlu menunggu perintah dari siapapun;

f. berhak memperoleh manfaat dari PT;

g. sebagai orang yang menjadi pemegang sesungguhnya dari uang PT atau pemilik saham PT.

PT haruslah memiliki unsur - unsur yang terkandung di Undang - Undang PT, yakni :11

1. Struktur keorganisasian yang disiplin

Struktur keorganisasian yang disiplin diketahui pada badan suatu PT dimana terdapat RUPS, anggota direksi berikut komisaris. Peraturan mengenai keorganisasian ini terlihat di dalam AD perusahaan, keputusan RUPS, keputusan direksi dan persetujuan dewan komisaris yang akan dikeluarkan ketika PT sedang berjalan.

2. Harta kekayaan

Modal dasar merupakan harta kekayaan yang merupakan semua nilai saham dengan berupa uang tunai dan berikut harta kekayaan di dalam wujud lain.

3. Menjalankan ikatan perjanjian hukum dengan orang lain

Perseroan yang berstatus badan hokum akan menjalankan sendiri ikatan hokum dengan mengiring orang lain atau pihak ketiga, dalam menjalankan ini PT diwakili oleh pengurusnya yakni anggota direksi dan komisaris. Direksi dengan sebutan Direktur siap mempunyai tanggung jawab untuk pengurusan perseroan, kepentingan dan tujuan perseroan dalam hal ini akan dilakukan di dalam ataupun di luar perseroan, tetapi tindakan Direksi ini berada di bawah pengawasan Dewan Komisaris, yang artinya setiap tindakan atau hubungan hukum perseroan yang diwakili oleh Direksi haruslah mendapat persetujuan dari Dewan Komisaris.

4. Memiliki tujuan sendiri

Tujuan dari perusahaan telah diatur di dalam anggaran dasar perusahaan, tidak lain adalah tujuan dari perusahaan adalah mendapatkan laba atau keuntungan.

Berhubung dengan tentang apa yang ditulis dan dijelaskan pada latar belakang masalah di atas, bahwa seiring dengan maraknya kasus tindakan pidana pencucian uang berikut pendanaan kepada teroris di Negara Indonesia yang berkedok atau dengan cara menyembunyikan hasil perilaku kriminal tersebut di dalam suatu perusahaan, presiden Republik Indonesia telah mengeluarkan PP dengan nomor 13 pada tahun 2018 mengenai cara untuk menerapkan prinsip mengenali si pemilik manfaat dari suatu perusahaan

${ }^{11}$ Wahyuni, Tri, Verti, (2017). Kepemilikan Tunggal Badan Hukum Perseroan Terbatas (PT). Jurnal Hukum Novelty, 8(2), 201-215. h. 203. 
untuk pencegahan dan memberantasi kasus tindakan pidana pencucian uang dan tindakan pidana pendanaan kepada terorisme. Maka diangkatlah sebuah judul dalam jurnal ini yaitu "Implementasi Peraturan Presiden Nomor 13 Tahun 2018 Dalam Pendirian Perseroan Terbatas".

\section{Metode Penelitian}

Jenis penelitian dalam jurnal adalah dengan meneliti menggunakan hokum empiris, karena tergambar pada tulisan di latar belakang masalah di atas, berusaha untuk meneliti untuk mendapatkan pengetahuan tentang bagaimanakah implementasi PP Nomor 13 Tahun 2018 dalam pendirian PT dan apakah pemilik manfaat di dalam perseroan semua sudah menerapkannya. ${ }^{12}$ Pendekatannya disini adalah mendekati fakta atau istilah asingnya the fact approach karena mengumpulkan fakta tentang bagaimanakah implementasi PP Nomor 13 Tahun 2018 dalam pendirian PT dan apakah pemilik manfaat dari perseroan terbatas sudah semua menerapkannya, dan berikutnya pendekatan dengan perundang - undangan atau istilah asingnya the statute approach. Datanya menggunakan primer dan sekunder, artiannya bahwa terdapat data yang asalnya dari lapangan tempat dimana terkait dengan permasalahan yang akan di bahas, yaitu dengan melakukan wawancara terhadap :

1. Notaris \& P.P.A.T Dewi Eka Koreati, SH, berkantor dan beralamat di Jalan Raya Dalung Nomor 77, Banjar Tegeh, Kelurahan/Desa Dalung, Kecamatan Kuta Utara, Kabupaten

Badung;

2. Notaris \& P.P.A.T I Wayan Sugitha, SH, berkantor dan beralamat di Jalan Patimura Nomor 63 - Denpasar,

dan data yang diambil dari belajar kepustakaan, yakni berupa literature, jurnal ilmiah, skripsi dan tesis yang mendukung lancarnya penelitian jurnal ini. Cara mengumpulkan datanya adalah memakai teknik

Teknik pengumpulan data dalam penelitian ini adalah menggunakan teknik pencarian (searching) di internet dan teknik wawancara. Menganalisis datanya dengan cara memaparkan hasil pencarian (searching) dari internet dan hasil wawancara kemudian diurutkan sedemikian mungkin sehingga mampu untuk mendukung jawaban dari permasalahan pada jurnal ini.

\section{Hasil dan Pembahasan}

\subsection{Implementasi Peraturan Presiden Nomor 13 Tahun 2018 Dalam Pendirian Perseroan Terbatas (PT)}

Pengertian "Implementasi" merupakan penerapan/pelaksanaan yang disusun sedemikian rupa dengan kecermatan, ketelitian maupun secara merinci. Adapun pengertian implementasi menurut para ahli yaitu :13

1. Dari Hunger dan Wheelen

Implementasi merupakan cara dan rencana yang bertujuan mewadahi dan melaksanakan suatu informasi di dalam operasi.

\footnotetext{
12 Jayanthi Devi, N.M., Wairocana, I.G.N., \& Wiryawan, I.W. (2015). Status Dan Kedudukan Lembaga Perkreditan Desa (LPD) Terkait Pengikatan Jaminan Dengan Berlakunya UndangUndang Nomor 1 Tahun 2013 Tentang Lembaga Keuangan Mikro. Acta Comitas, 201-212. h. 204.

${ }^{13}$ Alihamdan. Pengertian Implementasi. Available from https://blog.currentapk.com/implementasi/ (diakses 17 Desember 2018).
} 
Artinya bahwa, di dalam suatu aturan yang telah diatur haruslah aturan tersebut diterapkan dengan cara memberikan suatu informasi atau pembekalan tentang bagaimana aturan tersebut akan dijalankan.

2. Dari Van Horn dan Van Meter

"Implementasi" merupakan suatu keputusan yang diteruskan dengan tindakan oleh individu/seseorang, instansi pemerintah, jajaran pejabat, maupun kelompok swasta demi agar terwujudnya maksud dan tujuan yang telah diatur di dalam keputusan atau aturan tertentu.

Artinya bahwa, adanya suatu keputusan dan aturan tertentu yang telah dikeluarkan, wajib oleh individu/seseorang, instansi pemerintah, jajaran pejabat maupun kelompok swasta ikut membantu melaksanakan dengan cara menerapkan apa yang telah diputuskan atau diatur.

Jadi, implementasi merupakan suatu pelaksanaan atau penerapan yang dilakukan oleh individu, instansi pemerintah, pejabat, maupun kelompok swasta terhadap keputusan atau aturan yang ada atau yang telah dikeluarkan.

Cara penerapan aturan yang dikeluarkan oleh presiden dengan nomor 13 pada tahun 2018 mengenai cara penerapan prinsip untuk mengenali si pemilik manfaat dari perusahaan untuk melakukan pencegahan dan memberantasi kasus tindakan pidana money laundering dan pendanaan kepada terorisme dalam mendirikan PT, dituangkan dalam Pasal 14 Peraturan Presiden ini adalah :

1. Semua PT diwajibkan untuk menunjuk pegawai dan pejabat agar menjalankan dengan menerapi prinsip mengenali si pemilik manfaat dalam perusahaan;

2. Memberikan suatu info tentang perusahaan dan si pemilik manfaat dengan alasan permintaan dari pihak yang berwenang dan para aparat penegak hukum,

selanjutnya yang tertuang dalam Pasal 15 dijelaskan bahwa si pemilik manfaat dari perusahaan sesuai dengan Pasal 14 yaitu:

1. Mengidentifikasi si pemilik manfaat dengan menagih kartu identitasnya;

2. Mengverifikasi si pemilik manfaat dengan mengecek keabsahan kartu identitasnya.

Mengenali si pemilik manfaat ini dilakukan ketika melakukan mohon akta pendirian perseroan terbatas, adapun tentang pendaftarannya, proses pengesahan dan memperoleh persetujuannya berikut pengurusan ijin - ijin operasional perusahaan. Pada penerapannya dilakukan proses pengumpulan data pemilik manfaat yaitu sebagaimana telah diatur pada Pasal 16 yakni :

1. Nama lengkap ;

2. Nomor Identitas Kependudukan, Passport, Kitas atau Surat Ijin Mengemudi ;

3. Tempat/dan tanggal lahir ;

4. Status Kependudukan/Kewarganegaraan ;

5. Jalan rumah/tempat tinggal ;

6. Alamat di luar Negara Indonesia, dalam hal pemilik manfaat adalah warga Negara asing;

7. Nomor Pokok Wajib Pajak atau (NPWP);

8. Status hubungan pemilik manfaat dengan perusahaan.

Tujuannya adalah agar data legalitas pemilik manfaat lengkap dan dijamin keasliannya oleh pegawai, instansi yang berwenang, pejabat maupun kelompok swasta yang ditunjuk. Dalam hal ini penyampaian informasi tersebut dapat dilakukan oleh sipendiri maupun pengurus, oleh notaris dan/atau oleh pihak lain yang telah diberikan kuasa. 
Sehubungan dengan hal tersebut, berikut hasil wawancara dengan Bapak Notaris/PPAT I Wayan Sugitha, $\mathrm{SH}$ :

Sesuai dengan ketentuan yang dikeluarkan oleh presiden dengan nomor 13 pada tahun 2018 mengenai cara untuk penerapan prinsip dan mengenai si pemilik manfaat dari korporasi/perusahaan yang tujuannya adalah memberantas dan mencegah TPPU serta pendanaan kepada terorisme, si pemilik manfaat ini merupakan salah satu persyaratan dalam suatu dunia usaha, karena memiliki tujuan yang jelas yaitu untuk menghindari nominee dan kasus money laundering serta pendanaan kepada kaum teroris. Wujud pelaksanaan dari mengenali pemilik manfaat adalah dengan membuat Surat Pernyataan apabila terdapat pihak yang ingin berinvestasi, dalam artian bahwa mendirikan dan mengoperasikan sebuah usaha di hadapan Notaris, namun tanggung jawab untuk mengungkap siapa pemilik manfaat bukanlah menjadi tanggung jawab notaris, tetapi tanggung jawab tersebut tetap berada di pihak korporasi, dan Notaris hanya berkerjasama dengan Online Single Subsmmsion (OSS) dengan cara memasukkan atau menginput data akta perusahaan melalui system "Administrasi Hukum Umum" ( AHU ) Kementerian Hukum dan HAM RI terkait dengan siapa pemilik manfaat di dalam perusahaan tersebut. (Wawancara hari Kamis, tanggal 20 Desember 2018).

Bawasannya adalah Notaris di dalam Peraturan Presiden Nomor 13 Tahun 2018 tersebut sifatnya hanya membantu untuk menginformasikan kepada Instansi yang berwenang bahwa siapa yang menjadi pemilik manfaat dari perusahaan tersebut, dan dalam hal ini Notaris sendiri ditunjuk oleh korporasi itu sendiri.

\subsection{Pemilik Manfaat dari Perusahaan Sudah Semua Menerapkan Peraturan Presiden Nomor 13 Tahun 2018}

Pengertian pemilik manfaat dalam Peraturan Presiden Nomor 13 Tahun 2018 adalah orang/perseorangan yang berhak dan mampu memilih dan memecat Direktur berikut komisaris serta pengurus dan Pembina perusahaan, dan dia memiliki kemampuan untuk melaksanakan dan menyetir perusahaan. Disamping itu juga, sangat berhak memiliki keuntungan dari perusahaan dengan cara langsung maupun tidak langsung dan merupakan pemilik dari perusahaan yang sebenarnya.

Berikut hasil wawancara dengan Ibu Notaris/PPAT Dewi Eka Koreawati, SH.,M.Kn mengenai apakah semua pemilik manfaat menerapkan Peraturan Presiden Nomor 13 Tahun 2018 yakni :

Tidak semua Notaris mematuhi aturan yang terkandung dalam Peraturan Presiden Nomor 13 Tahun 2018, sebabnya karena sangat beresiko tinggi bagi Notaris itu sendiri, bahwa Notaris akan mengetahui siapa sebenarnya pemilik manfaat dari perusahaan itu sendiri, dan pasalnya bahwa Notaris hanya menuangkan apa yang ia dengar dari klien, bawasannya adalah hanya para pemegang saham yang disebutkan di dalam anggaran dasar perseroan terbatas (PT), sedangkan Notaris sebenarnya tidak diwajibkan untuk bertanya tentang siapakah pemilik manfaat dari perusahaan ini karena Notaris hanya menuangkan apa yang menjadi kehendak daripada klien itu sendiri.

Jadi, notaris tetap mematuhi aturan di dalam Undang - Undang Jabatan Notaris ( UUJN ) yang dituangkan dalam aturan Pasal 15 ayat ( 1 ) yakni bahwa Notaris mempunyai kewenangan untuk membikin akta autentik dengan segala perkataan, perbuatan yang dituangkan di dalam suatu perjanjian, dan berikut penetapan atas aturan perundang - 
undangan, tak lain bahwa semua yang dikehendaki oleh klien untuk kepentingan klien itulah yang dituangkan oleh notaris ke dalam aktanya, serta tidak lupa akan menjamin tanggal akta, waktu pembuatan akta, proses penyimpanan akta berikut pada saat pemberian salinan/grosse akta.

\section{Kesimpulan}

Implementasi Peraturan Presiden Nomor 13 Tahun 2018 dalam pendirian perseroan terbatas (PT) adalah berupa Surat Pernyataan oleh Pemilik Manfaat yang menyatakan bahwa memang benar dirinya adalah pemilik manfaat dan sebagai pemegang modal dan penyetor dana di dalam perusahaan. Oleh Notaris adalah membantu menginformasikan pernyataan tersebut kepada Instansi yang berwenang. Tidak semua pemilik manfaat mengetahui aturan yang terkandung di dalam aturan yang telah dikeluarkan oleh presiden dengan nomor 13 pada tahun 2018 ini, begitupun sebaliknya tidak semua Notaris menerapkan aturan tersebut dikarenakan merasa beresiko mengetahui siapa sebenarnya pemilik manfaat dari perusahaan, dan masih tunduk dan berpegang teguh dengan UUJN yakni hanya menuangkan apa yang menjadi kehendak klien ke dalam akta. Dapat disarankan, implementasi Peraturan Presiden Nomor 13 Tahun 2018 yang berupa Surat Pernyataan yang terlampir pada saat mendirikan Perseroan Terbatas (PT) selayaknya bisa membantu para pendiri serta pengurus Perseroan Terbatas (PT) terbebas dari pemeriksaan karena kecurigaan adanya tindak pidana pencucian uang.

\section{Daftar Pustaka \\ $\underline{\text { Buku }}$}

Garnasih, Yenti. (2016). Penegakan Hukum Anti Pencucian Uang Dan Permasalahannya Di Indonesia. PT. RajaGrafindo Persada, Jakarta.

Is, M.S. (2016). Hukum Perusahaan di Indonesia. Jakarta: PT. Kharisma Putra Utama.

\section{Jurnal}

Budiono, H. (2012). Arah Pengaturan Undang-Undang Nomor 40 Tahun 2007 tentang Perseroan Terbatas dalam Menghadapi Era Global. Jurnal Rechts Vinding: Media Pembina Hukum Nasioal, 1(2), 187-198.

Hariman, Satria. (2016). Pertanggungjawaban Pidana Korporasi Dalam Tindak Pidana Sumber Daya Alam. Jurnal Bagian Hukum Pidana, Fakultas Hukum Universitas Muhammadiyah Kendari, Kendari, Mimbar Hukum Volume 28, Nomor 2, Juni 2016, Halaman 288-300

Kurniawan, I. (2013). Perkembangan Tindak Pidana Pencucian Uang (Money Laundering) dan Dampaknya Terhadap Sektor Ekonomi dan Bisnis. Jurnal Ilmu Hukum Riau, 3(2).

Kurniawan. (2014). Tanggung Jawab Pemegang Saham Perseroan Terbatas Menurut Hukum Positif. Jurnal Bagian Hukum Bisnis, Fakultas Hukum Universitas Mataram, Mimbar Hukum Volume 26, Nomor 1, Februari 2014, Halaman 70-83.

Jayanthi, N. M. D., \& Wiryawan, I. W . (2018). Status Dan Kedudukan Lembaga Perkreditan Desa (LPD) Terkait Pengikatan Jaminan Dengan Berlakunya UndangUndang Nomor 1 Tahun 2013 Tentang Lembaga Keuangan Mikro. Acta Comitas, 201-212.

Listyowati, N. (2015). Tanggung Jawab Hukum Perseroan Terbatas Yang Belum Berstatus Badan Hukum. E-Jurnal Spirit Pro Patria, 1(2).

Santoso, J. (2000). Perseroan Terbatas Sebagai Institusi Kegiatan Ekonomi yang Demokratis. Jurnal Hukum Ius Quia Iustum, 7(15), 194-203. 
Wahyuni, V. T. (2017). Kepemilikan Tunggal Badan Hukum Perseroan Terbatas (PT). Jurnal Hukum Novelty, 8(2), 201-215.

Yani, M. A. (2013). Kejahatan Pencucian Uang (Money Laundering) (Tinjauan UndangUndang Nomor 8 Tahun 2010 Tentang Pencegahan Dan Pemberantasan TindakPidana Pencucian Uang). E-Journal Widya Yustisia, 1(1).

\section{Website}

DBS Bank Ltd (SG). (2018). Yuk Ketahui Seperti Apa Sistem Ekonomi Indonesia di 2018. Retrieved from https://www.dbs.com/Indonesia-bh/blog/live-smart/yuk-ketahui-sepertiapa-sistem-ekonomi-indonesia-di-2018.page, diakses 16 Desember 2018.

Alihamdan. (2018). Pengertian Implementasi. Retrieved from https://blog.currentapk.com/implementasi/, diakses 17 Desember 2018.

\section{Peraturan Perundang - Undangan}

Undang - Undang Negara Republik Indonesia Nomor 30 Tahun 2004 tentang Jabatan Notaris (Lembaran Negara Republik Indonesia Tahun 2004 Nomor 117).

Undang - Undang Negara Republik Indonesia Nomor 40 Tahun 2007 tentang Perseroan Terbatas (Lembaran Negara Republik Indonesia Tahun 2007 Nomor 106).

Undang-Undang Republik Indonesia Nomor 8 Tahun 2010 tentang Pencegahan dan Pemberantasan Tindak Pidana Pencucian Uang (Lembaran Negara Republik Indonesia Tahun 2010 Nomor 122).

Peraturan Presiden Republik Indonesia Nomor 13 Tahun 2018 tentang Penerapan Prinsip Mengenali Pemilik Manfaat Dari Korporasi Dalam Rangka Pencegahan Dan Pemberantasan Tindak Pidana Pencucian Uang dan Tindak Pidana Pendanaan Terorisme. 